\title{
Evaluation of gamma radiation-induced DNA damage in Aedes aegypti using the comet assay
}

Toxicology and Industrial Health $1-8$

(C) The Author(s) 2017 Reprints and permissions: sagepub.co.uk/journalsPermissions.nav DOI: 10.1 177/07482337|7733599 journals.sagepub.com/home/tih (S)AGE

\author{
Vinaya Shetty', NJ Shetty', SR Ananthanarayana², \\ SK Jha ${ }^{3}$ and RC Chaubey ${ }^{4}$
}

\begin{abstract}
The study was undertaken to evaluate gamma radiation-induced DNA damage in Aedes aegypti. The comet assay was employed to demonstrate the extent of DNA damage produced in adult male $A$. aegypti exposed to seven different doses of gamma radiation, ranging from I Gy to $50 \mathrm{~Gy}$. DNA damage was measured as the percentage of comet tail DNA. A significant linear increase in DNA damage was observed in all samples; the extent of damage being proportional to the dose of gamma radiation the organism received, except in those treated with I Gy. The highest amount of DNA damage was noticed at I h postirradiation, which decreased gradually with time, that is, at 3,6 and $12 \mathrm{~h}$ postirradiation. This may indicate repair of the damaged DNA and/ or loss of heavily damaged cells as the postirradiation time increased. The comet assay serves as a sensitive and rapid technique to detect gamma radiation-induced DNA damage in A. aegypti. This could be used as a potential biomarker for environmental risk assessment.
\end{abstract}

\section{Keywords}

Gamma radiation, DNA damage, comet assay, genotoxicity

Received 9 April 2017; Revised 19 July 2017; Accepted 24 August 2017

\section{Introduction}

Living organisms are constantly exposed to ionizing radiations from radionuclides that exist in various natural and artificial sources. In past decades, scientific and regulatory activities related to radiation protection focused on the radiation exposure of humans. The prevailing view has been that if humans were adequately protected, then other living things are also likely to be sufficiently protected (EMRAS, 2007; Moller and Mousseau, 2013). Over time, the general validity of this view has been questioned on occasion, and therefore, consideration has been given to the potential effects of exposure to ionizing radiation on non-human biota (UNSCEAR, 2011). The study of radiological effects on various plants and animals is currently a subject of widespread scientific interest (Singhal et al., 2009).

Aedes aegypti is the primary vector for dengue fever/dengue haemorrhagic fever (DF/DHF) and major public health problems in many subtropical and tropical countries (Ahmad et al., 2007). It is also the best known insect species from the standpoint of both basic and applied science. Because of its ready adaptability to laboratory culture and short lifespan with high reproductive potential, this species has been used as a test animal for many physiological, developmental and genotoxicity studies (Craig and Hickey, 1967;

\footnotetext{
'Centre for Applied Genetics, Bangalore University, Bengaluru, India

${ }^{2}$ Department of Sericulture, Bangalore University, Bengaluru, India

${ }^{3}$ Environmental Assessment Division, Bhabha Atomic Research Centre, Mumbai, India

${ }^{4}$ Radiation Biology and Health Science Division, Bhabha Atomic Research Centre, Mumbai, India
}

Corresponding author:

NJ Shetty, Centre for Applied Genetics, Bangalore University, JB Campus, Bengaluru 560056, India.

Email: shetty_nj@yahoo.co.in 
Clemons et al., 2010). It has been extensively reported that gamma radiations can break covalent bonds and can directly affect DNA structure by inducing DNA breaks, particularly single-strand breaks and double-strand breaks (DSBs) in living cells (Azzam et al., 2012; Borrego-Soto et al., 2015; Lee and Steinert, 2003).

Numerous methods have been developed for detecting damage to DNA strands (Tice et al., 2000). Single cell gel electrophoresis (SCGE), also known as the comet assay, is an extremely promising genotoxicity test developed in recent years to measure and analyse DNA damage in single cells. SCGE is less resource intensive than conventional genotoxic techniques and permits both qualitative and quantitative assessment of DNA damage in any eukaryotic cell population. The simplicity and sensitivity of the comet assay has resulted in a rapid and widespread application of this technique in many areas, including environmental monitoring (Cavallo et al., 2002; Rajaguru et al., 2002), in vivo and in vitro genotoxicity testing (Anderson et al., 1996; 2001; Dhawan et al., 2002) and epidemiological and biomonitoring studies in human populations exposed to radiation occupationally, environmentally or clinically (Bajpayee et al., 2002; Marczynski et al., 2002; Mohankumar et al., 2002). The assay detects DNA strand breakage and alkali-labile sites by measuring the migration of DNA from immobilized individual cell nuclei.

Invertebrates are an interesting subject of ecotoxicological research because of their significance in ecosystems. In this context, the comet assay has been successfully used for genotoxicity assessment in marine and freshwater invertebrates (Cotelle and Ferard, 1999; Lee and Steinert, 2003; Mitchelmore and Chipman, 1998). More specifically, it can be applied to explore pesticide resistance or the selection of environmental pollutant immunity, as well as to better understand the ageing of insects. To date, terrestrial species of several orders, including insects that are significant to the human economy, have been examined using this assay. This includes organisms such as Liriomyza trifolii of order Diptera (Koo et al., 2012); Tenebrio molitor (Wright et al., 2004), Curculio sikkimensis (Todoriki et al., 2006), Sitophilus zeamais (Hasan et al., 2008), and Lasioderma serricorne (Kameya et al., 2012) of order Coleoptera; Plodia interpunctella (Imamura et al., 2004), Plutella xylostella (Koo et al., 2011) of order Lepidoptera; and aquatic species, including Chironomus riparius (Martinez-Paz et al., 2013; Morales et al., 2013) and
Chironomus kiiensis (Al-Shami et al., 2012). Undoubtedly, evaluations of damage to genetic material will be important in insects that are of substantial importance to humans, such as crop pests, disease vectors and social insects. In view of this, the present study was undertaken to assess the different doses of gamma radiation-induced genotoxicity in $A$. aegypti at different time intervals using the alkaline comet assay.

\section{Materials and methods}

\section{Mosquito rearing}

A. aegypti larvae collected from the J. P. Nagar area of Bengaluru, India were reared at $25 \pm 1{ }^{\circ} \mathrm{C}$ and $75 \pm 5 \%$ relative humidity under a 14 -h photoperiod in the insectary of the Centre for Applied Genetics, Bangalore University following standard protocol (Shetty, 1983).

\section{Gamma irradiation}

Experiments were performed in triplicate, along with a control. Overall, a total of 1680 adult males, 2-3 days of age, were irradiated with different doses of gamma radiation from a ${ }^{60} \mathrm{Co}$ (Theratron $780-\mathrm{C}$ Telecobalt Unit, AECL, Ontario, Canada) source with a dose rate of $253.56 \mathrm{cGy} / \mathrm{min}$ at the Kidwai Memorial Institute of Oncology, Bengaluru. The mosquitoes were placed in plastic boxes $(5 \times 4 \times 2.5 \mathrm{~cm})$ covered with fine net cap during irradiation. Doses of $1,5,10$, 20,30, 40 and 50 Gy were chosen for the study. Dosimetry was employed to quantify the dose received by the irradiated insects and confirm that all the doses delivered lay within a 5\% error range. Each batch consisted of 240 adult mosquitoes receiving a specific dose of the radiation. The irradiated mosquitoes maintained in the insectary for further analysis.

\section{Genotoxicity study using comet assay}

The DNA damage studies were carried out using SCGE. The protocol followed is described by Singh et al. (1988) with minor modifications as described below.

\section{Slide preparation}

Whole body homogenates were prepared by pooling 20 irradiated males, each at four different time intervals, that is, 1, 3, 6 and 12-h postirradiation. A control set was prepared in a similar manner. Twenty 


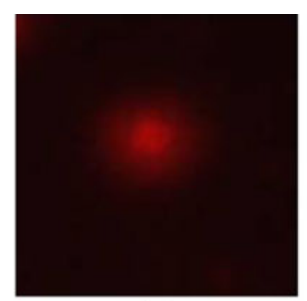

(a)

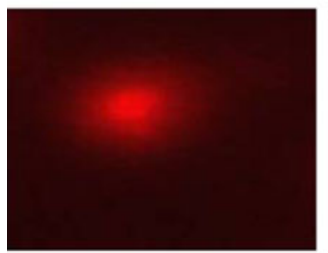

(e)

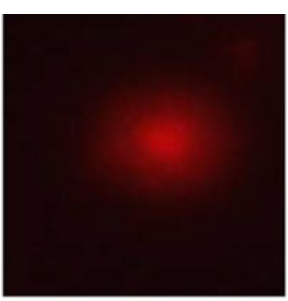

(b)

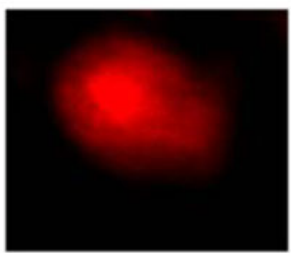

(f)

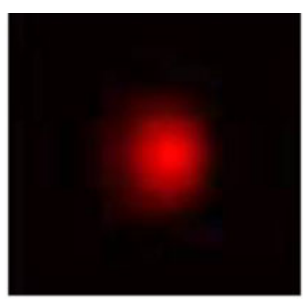

(c)

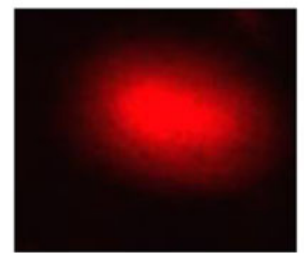

(g)

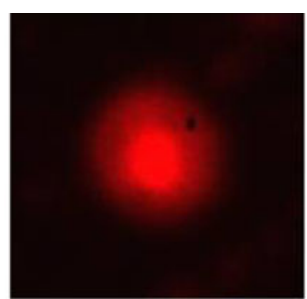

(d)

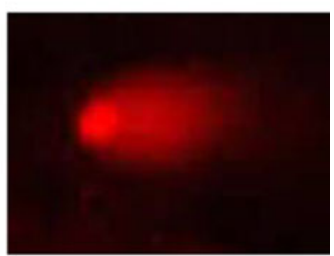

(h)

Figure I. Representative figures of the comet assay at I h postirradiation. (a) Control, (b) I Gy, (c) 5 Gy, (d) I0 Gy, (e) $20 \mathrm{~Gy}$, (f) $30 \mathrm{~Gy}$, (g) $40 \mathrm{~Gy}$ and (h) $50 \mathrm{~Gy}$.

mosquitoes were homogenized in $10 \%(\mathrm{w} / \mathrm{v})$ homogenizing buffer ( $0.075 \mathrm{M} \mathrm{NaCl}$ and $0.024 \mathrm{M}$ EDTA). The homogenate mixture was centrifuged at $1000 \mathrm{r} / \mathrm{min}$ for 10 min using a cold centrifuge at $4^{\circ} \mathrm{C}$. The pellets were gently resuspended in $1 \mathrm{ml}$ of chilled homogenizing buffer for nuclei preparation. Roughened frozen microscopic slides were marked, placed horizontally and then a thin, homogenous layer of $1 \%$ normal melting agarose was cast onto the slide. The slides were dried at room temperature and then placed at $4^{\circ} \mathrm{C}$ until used. Subsequently, each precoated slide was cast with $100 \mu \mathrm{l}$ of isolated nuclei and $1 \%$ low melting agarose (1:4) mixture using a cover slip and allowed to solidify at $4^{\circ} \mathrm{C}$ for $20 \mathrm{~min}$. After the removal of the cover slip, the slides were immersed into freshly prepared chilled lysis buffer (2.5 M NaCl, $100 \mathrm{mM}$ EDTA pH 10, 5\% DMSO and $1 \%$ Triton $\mathrm{X}-100$ ) for $1 \mathrm{~h}$ in the dark, at $4^{\circ} \mathrm{C}$. Following this, the slides were incubated in alkaline electrophoresis buffer (1 mM EDTA and $300 \mathrm{mM}$ $\mathrm{NaOH}, \mathrm{pH}>13)$ in an ice-cold electrophoresis chamber for $20 \mathrm{~min}$ to facilitate unwinding of DNA strands; the process was subsequently conducted for $20 \mathrm{~min}$ at $25 \mathrm{volts} / 300 \mathrm{~mA}$. The slides were washed thrice by incubating the slides for $5 \mathrm{~min}$ each in neutralizing buffer (0.4 M Tris, $\mathrm{pH} 7.5)$. Just before visualization, the slides were stained with ethidium bromide $(20 \mu \mathrm{g} / \mathrm{ml}, 40 \mu \mathrm{l} / \mathrm{slide})$ for $10 \mathrm{~min}$ in the dark or without direct exposure to light. The slides were then washed once in chilled distilled water by dipping to remove excess ethidium bromide and subsequently were covered with a cover slip. The slides were stored in a dark, humidified chamber and analysed within $3 \pm 4 \mathrm{~h}$.

\section{Comet capture}

A total of 50 cells from each slide were analysed at $40 \times$ magnification, using a Zeiss Axioskop 2 fluorescence microscope (ZEISS, Germany) with an extinction filter of $515-560 \mathrm{~nm}$ and a barrier filter of $590 \mathrm{~nm}$. AxioVision Rel. 4.8 software was used for photography. Comet tail length and the percentage of DNA damage in the tail were measured with CASP comet software (CaspLab 1.2.3beta2 version).

\section{Statistical analysis}

Analysis of variance (ANOVA)-General Linear Model (GLM) followed by Tukey's post hoc test was performed to analyse the significant difference in the percentage of tail DNA in-between test samples. In addition, trend analysis in the form of linear regression was performed using SPSS, and a significant dose-rate response relationship was indicated by a slope significantly different $(p \leq 0.05)$ from zero.

\section{Results}

This study detects, at the microscopic level, the extent of DNA damage on a temporal scale ranging from 1 to $12 \mathrm{~h}$, following gamma irradiation with doses ranging from 1 to $50 \mathrm{~Gy}$. The postirradiation DNA damage as observed in individual cells of adult $A$. aegypti is illustrated in Figure 1. This representation figure 


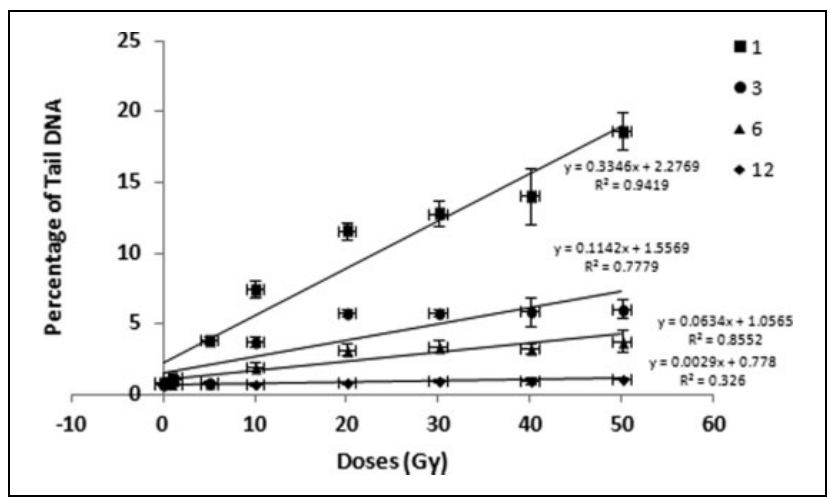

Figure 2. Dose-response relationship for DNA damage at $\mathrm{I} \mathrm{h,} 3 \mathrm{~h}, 6 \mathrm{~h}$ and $12 \mathrm{~h}$ after gamma irradiation on adult male Aedes aegypti.

shows the comet assay images of adult $A$. aegypti taken $1 \mathrm{~h}$ after irradiation to different doses of gamma rays. Gamma radiation breaks DNA strands, increasing the migration of short-chain fragments leading to the formation of a comet-like shape with a long tail, following electrophoresis. The dose- and timedependent increase of DNA damage, induced by gamma radiation, and their statistical significance are represented in Figure 2.

A significant increase in DNA damage was observed in all the samples of A. aegypti irradiated with various doses of gamma radiation except those treated with 1 Gy ( $1 \mathrm{~h}$ postirradiation), 1 and $5 \mathrm{~Gy}(3 \mathrm{~h}$ postirradiation), 1, 5 and $10 \mathrm{~Gy}$ (6 h postirradiation), and $12 \mathrm{~h}$ postirradiation for all doses, which did not show a significant increase $(p \geq 0.05)$ in the percentage tail DNA with reference to the control.

The dose-response study showed that there was a dose-dependent increase in the intensity of radiation and DNA damage with a minimum percentage of tail DNA $(1.22 \pm 0.24)$ at the lowest dose of $1 \mathrm{~Gy}$ and the maximum percentage of tail DNA $(18.64 \pm 1.36)$ at the highest dose of $50 \mathrm{~Gy}$ at $1 \mathrm{~h}$ postirradiation. It was also observed that the dose-response effect was linear for different time points (i.e. $1 \mathrm{~h}, 3 \mathrm{~h}$ and $6 \mathrm{~h}$ ) except 12 $h$ postirradiation. When significant dose-rate response trends were found using linear regression, the goodness of fit ( $R^{2}$ adjusted) was high for the samples exposed to different doses of gamma radiation and at the time intervals, that is, $1 \mathrm{~h}, 3 \mathrm{~h}$ and $6 \mathrm{~h}$ after radiation except in the samples $12 \mathrm{~h}$ postirradiation (Figure $2 ; 1 \mathrm{~h}$, slope $=0.334, R^{2}=94 \%, p \leq 0.05 ; 3 \mathrm{~h}$, slope $=0.114, R^{2}=$ $77 \%, p \leq 0.05 ; 6 \mathrm{~h}$, slope $=0.063, R^{2}=85 \%, p \leq$ $0.05 ; 12 \mathrm{~h}$, slope $\left.=0.002, R^{2}=32 \%, p \geq 0.05\right)$. There were few comets of the apoptotic types found in each dose especially at $1 \mathrm{~h}$ postirradiation. Since these comets showed a very high percentage of tail DNA (ranging from $50 \%$ to $80 \%$ ), they were not considered for the count as comets of the apoptotic types give high variation in the mean percentage of tail DNA. A oneway ANOVA of the data on the dose-dependent DNA damage observed in the control and treated samples showed significance at $p \leq 0.05(F=97.44)$ at the first three time points studied (i.e. $1 \mathrm{~h}, 3 \mathrm{~h}$ and $6 \mathrm{~h}$, respectively).

A time-response study indicated significant DNA damage at initial three time points, that is, at $1 \mathrm{~h}, 3 \mathrm{~h}$ and $6 \mathrm{~h}$ for the 10,20,30,40 and 50 Gy doses of gamma radiation that were studied. Samples of adult A. aegypti for all the above said doses, post $12 \mathrm{~h}$ of irradiation on the other hand, did not show any significant difference $(p \geq 0.05)$ in the percentage of tail DNA, when compared to the control. The highest DNA damage $(18.64 \pm 1.36)$ was observed in the $1 \mathrm{~h}$ post-treatment 50 Gy exposed samples, and it decreased at the later time points reaching a minimum $(3.81 \pm 0.75)$ at $6 \mathrm{~h}$ and normal $(1.16 \pm 0.18)$ at $12 \mathrm{~h}$ postirradiation $(1 \mathrm{~h}, p \leq 0.05 ; 3 \mathrm{~h}, p \leq 0.05 ; 6 \mathrm{~h}$, $p \leq 0.05 ; 12 \mathrm{~h}, p \geq 0.05)$. A similar trend was also observed for the other doses 5, 10, 20, 30 and $40 \mathrm{~Gy}$.

\section{Discussion}

Gamma rays are known to induce various types of cellular and subcellular damage in living organisms (Garrison and Uyeki, 1988). Radiation, which acts on the cellular components, breaks chemical bonds (and also DNA DSBs) and provokes the production of free radicals, which results in oxidation and subsequent damage. The comet assay has previously confirmed that irradiation (both electron beam and gamma ray induced) can cause severe DNA damage in a dosedependent manner in the investigated species (Augustyniak et al., 2016). Several studies have been conducted to evaluate radiation-induced DNA damage in agricultural pests, such as the Indian meal moth $P$. interpunctella (Imamura et al., 2004), the maize weevil S. zeamais (Hasan et al., 2008), the diamondback moth P. xylostella (Koo et al., 2011) and the Oriental leafworm moth Spodoptera litura (Yun et al., 2014). However, this is the first time a similar study has been conducted on the mosquito vector species, A. aegypti.

We show a significant increase in gamma radiation-induced DNA damage by an increase in the mean percentage of tail DNA, using the comet assay at doses ranging from 5 Gy to 50 Gy of gamma 
radiation, when compared to the control. From the study, the data indicated that gamma radiation is a potential genotoxic inducer in A. aegypti, especially at $1 \mathrm{~h}$ postirradiation in all the doses ranging from 5 Gy to 50 Gy. Exposure to $1 \mathrm{~Gy}$, however, showed no significant increase in the percentage of tail DNA at any time point, when compared to the control. In a similar radiation study on $S$. zeamais, exposure to doses $0.5 \mathrm{kGy}$ and $1 \mathrm{kGy}$ was analysed using the comet assay, which recorded an increase in DNA damage with an increase in radiation dose for all the developmental stages, clearly indicating that radiation-induced DNA damage in all the stages was dose dependent (Hasan et al., 2008). Todoriki et al. (2006) employed the comet assay to evaluate electron beam radiation sensitivities in mature larvae of chestnut weevil, C. sikkimensis, and showed that DNA damage increases significantly as dose increases.

In the current study, we employed a temporal comet assay to understand DNA damage following gamma radiation. The study showed that significant DNA damage occured at 3 and $6 \mathrm{~h}$ postirradiation, showing a minimum amount of increase in the percentage of tail DNA, and $12 \mathrm{~h}$ postirradiation showed no significant increase in the percentage of tail DNA for any of the doses exposed. The results, thus, suggest that the genotoxic effect of gamma radiation does not last for a long period in A. aegypti. In a similar manner, DNA damage in L. serricorne exposed to gamma radiation of $1 \mathrm{kGy}$ was evaluated using the comet assay under alkaline conditions, wherein broken DNA strands appeared to be repaired as the postirradiation period lengthened (Kameya et al., 2012). The decrease in genetic damage at later times may indicate either repair of damaged DNA or loss of heavily damaged cells or both (Revankar and Shyama, 2009; Saleha Banu et al., 2001).

It was recorded that high-dose irradiation (30 Gy) lengthened the prepupal period in wild-type (Canton $\mathrm{S}$ and Oregon $\mathrm{R}$ ) and mutant strains such as DNA damage sensing (mei-41), DNA repair (mus209, mus210, mus309, rad54) and free radical detoxification (sod) strains of Drosophila melanogaster. The obtained results suggest the important role of free radical detoxification, DNA damage sensing and DNA repair mechanisms in the whole organism radiation-induced effects (Shaposhnikov et al., 2009). Exposure of gamma radiation doses (1-50 Gy) to $A$. aegypti showed a 10-12 days' increase in longevity at $4 \mathrm{~Gy}$; however, the lifespan decreased following exposure to higher doses ranging from
30 Gy to 50 Gy (Shetty et al., 2016). Such hormetic dose responses to gamma radiation have been recorded in many insect species (Seong et al., 2011; Vaiserman et al., 2003). Similar results were recorded in a study on the adult/pupal stages of Anopheles arabiensis, where it was shown that an overall similar or higher survival is observed in the irradiated samples when compared to the control (Helinski et al., 2006). For Anopheles pharoensis, a slight increase in longevity of males irradiated with doses ranging from 5 Gy to 70 Gy was reported (Abdel-Malek et al., 1966). Irradiation-induced reduction in longevity has been recorded in several anopheline species such as Anopheles stephensi, An. pharoensis and Anopheles gambiae s.s. as the dose increases beyond $80 \mathrm{~Gy}$ (Abdel-Malek et al., 1967; Curtis, 1976; Sharma et al., 1978). In D. melanogaster, it was shown that DNA damage and the following overexpression of different DNA repair genes led to both positive and negative effects on lifespan and stress resistance (Shaposhnikov et al., 2015).

The possible mechanism of radiation-induced DNA damage in A. aegypti may be the generation of reactive oxygen species (ROS) by gamma radiation, therefore causing DNA damage. ROS at high and/or sustained levels can cause severe damage to DNA, protein and lipids (Lau et al., 2008). Various stressors present in the environment, including pesticides and radiation, are capable of reacting with DNA and causing DNA damage. Stressors also have the capability to generate ROS, one of the possible mechanisms for the induction of DNA damage may be through the generation of ROS (Joseph et al., 2014; Rastogi et al., 2014; Wilson et al., 2003). After irradiation, the ability of an insect to survive and reproduce is closely related to the level of DNA damage (Augustyniak et al., 2016; Yun et al., 2014). The effects that are detected by SCGE, such as chromosomal aberrations due to DSBs and less extensive damage, especially in germ cells, can affect the fitness of the entire population if it reaches a critical level (Augustyniak et al., 2016). A. aegypti is also a wellknown mosquito vector for dengue, chikungunya and DHF (Gubler, 1998). Numerous vector control measures have been initiated to curb its proliferation. One such measure includes the radiation-induced sterile insect technique (SIT) which involves the release of sterile males into the environment in an attempt to control its population. Several irradiation studies have been conducted and isolated radiation-induced chromosomal translocations in mosquito species such as 
Culex quinquefasciatus (Shetty, 1993), Culex pipiens complex (Bhalla et al., 1974), Anopheles fluviatilis (Shetty, 1983), An. stephensi (Gayathri and Shetty, 1992) and A. aegypti (Rai et al., 1970), and it was shown that it could be effectively employed for genetic control programmes. It was also noted that in combination with selecting appropriate translocations, the doses of ionizing radiation which induced potentially deleterious effects while extending lifespan, probably offer an effective method of genetic control of mosquitoes using SIT (Shetty et al., 2016).

From this study, it appears that the alkaline comet assay is a promising technique to assess the genotoxic potential of gamma radiation in A. aegypti. A dosedependent increase and a time-related decrease of genotoxicity of gamma radiation were observed in A. aegypti. This could be used as a sensitive biomarker for environmental risk assessment. Further, this assay may be used to explain the connection between the stress that is induced by radiation and DNA damage, as well as the repair efficiency under limited energy conditions.

\section{Acknowledgements}

We are grateful to the Department of Radiation Physics, Kidwai Memorial Institute of Oncology, Bengaluru, for providing radiation facility.

\section{Declaration of Conflicting Interests}

The author(s) declared no potential conflicts of interest with respect to the research, authorship, and/or publication of this article.

\section{Funding}

This work was supported by the grants of the Board of Research in Nuclear Sciences (BRNS), Department of Atomic Energy (DAE), Bhabha Atomic Research Centre (BARC), Mumbai (No.2009/36/80-BRNS/2394 Dated 9/ 12/2009).

\section{References}

Abdel-Malek AA, Tantawy AO and Wakid AM (1966) Studies on the eradication of Anopheles pharoensis Theobald by the sterile-male technique using cobalt60. I. Biological effects of gamma radiation on the different developmental stages. Journal of Economic Entomology 59: 672-678.

Abdel-Malek AA, Tantawy AO and Wakid AM (1967) Studies on the eradication of Anopheles pharoensis Theobald by the sterile-male technique using cobalt60 . III. Determination of the sterile dose and its biological effects on different characters related to "fitness" components. Journal of Economic Entomology 60: 20-23.

Ahmad I, Astari S and Tan M (2007) Resistance of Aedes aegypti (Diptera: Culicidae) in 2006 to pyrethroid insecticides in Indonesia and its association with oxidase and esterase levels. Pakistan Journal of Biological Sciences 10(20): 3688-3692.

Al-Shami SA, Rawi CSM, Ahmad AH, et al. (2012) Redescription of Chironomus javanus and Chironomus kiiensis (Diptera: Chironomidae) larvae and adults collected from a rice field in Pulau Pinang, Malaysia. Tropical Life Sciences Research 23(1): 77-86.

Anderson D, Dhawan A, Yardley-Jones A, et al. (2001) Effect of antioxidant flavonoids and a food mutagen on lymphocytes of a thalassemia patient without chelation therapy in the comet assay. Teratogenesis, Carcinogenesis, and Mutagenesis 21(2): 165-174.

Anderson D, Dhawan A, Yu TW, et al. (1996) An investigation of bone marrow and testicular cells in vivo using the comet assay. Mutation Research 370(3-4): 159-174.

Augustyniak M, Gladysz M and Dziewiecka M (2016) The comet assay in insects - status, prospects and benefits for science. Mutation Research/Reviews in Mutation Research 767: 67-76.

Azzam EI, Jay-Gerin JP and Pain D (2012) Ionizing radiation-induced metabolic oxidative stress and prolonged cell injury. Cancer Letters 327: 48-60.

Bajpayee M, Dhawan A, Parmar D, et al. (2002) Genderrelated differences in basal DNA damage in lymphocytes of a healthy Indian population using the alkaline comet assay. Mutation Research 520(1-2): 83-91.

Bhalla SC, Cajaiba ACI, Carvallo WMP, et al. (1974) Translocations inversions and correlation of linkage groups to chromosomes in the mosquito Culex fatigans. Canadian Journal of Cytology and Genetics 6: 837-850.

Borrego-Soto G, Ortiz-LÃpez R and Rojas-MartÃnez A (2015) Ionizing radiation-induced DNA injury and damage detection in patients with breast cancer. Genetics and Molecular Biology 38: 420-432.

Cavallo D, Tomao P, Marinaccio A, et al. (2002) Evaluation of DNA damage in flight personnel by comet assay. Mutation Research 516(1-2): 148-152.

Clemons A, Haugen M, Flannery E, et al. (2010) Aedes aegypti: an emerging model for vector mosquito development. Cold Spring Harbor Protocols 2010. DOI: $10.1101 /$ pdb.emo141.

Cotelle S and Ferard JF (1999) Comet assay in genetic ecotoxicology: a review. Environmental and Molecular Mutagenesis 34(4): 246-255. 
Craig JGB and Hickey WA (1967) Genetics of Aedes aegypti. In: Wright JWRP (ed) Genetics of Insect Vectors of Diseases. Amsterdam: Elsevier, p. 67.

Curtis CF (1976) Radiation sterilization. Report on mosquito research. Ross Institute of Tropical Hygiene. 01.01.76-31.12.77.

Dhawan A, Anderson D, de Pascual-Teresa S, et al. (2002) Evaluation of the antigenotoxic potential of monomeric and dimeric flavanols, and black tea polyphenols against heterocyclic amine-induced DNA damage in human lymphocytes using the comet assay. Mutation Research 515(1-2): 39-56.

EMRAS (2007) (Environmental Modeling for Radiation Safety), Modelling Radiation Exposure and Radionuclide Transfer for Non-human Species (Report of the Biota Working Group of EMRAS Theme 3). Available at: http://www-ns.iaea.org/downloads/rw/projects/emras/ final-reports/biota-final.pdf (accessed 3 February 2013).

Garrison JC and Uyeki EM (1988) The effects of gamma radiation on chondrogenic development in vitro. Radiation Research 116(2): 356-363.

Gayathri DK and Shetty NJ (1992) Chromosomal translocation and inherited semisterility in the malaria vector Anopheles stephensi. Journal of Communicable Diseases 24: 70-74.

Gubler DJ (1998) Dengue and dengue hemorrhagic fever. Clinical Microbiology Reviews 11(3): 480-496.

Hasan MD, Todoriki S, Miyanoshita A, et al. (2008) Detection of gamma radiation-induced DNA damage in maize weevil, Sitophilus zeamais Motschulsky (Coleoptera: Curculionidae) assessed using the comet assay. International Journal of Radiation Biology 84(10): 815-820.

Helinski MEH, Parker AG and Knols BGJ (2006) Radiation-induced sterility for pupal and adult stages of the malaria mosquito Anopheles arabiensis. Malaria Journal 5(1): 41.

Imamura T, Todoriki S, Sota N, et al. (2004) Effect of softelectron (low-energy electron) treatment on three stored-product insect pests. Journal of Stored Products Research 40(2): 169-177.

Joseph P, Bhat NN, Copplestone D, et al. (2014) Production of gamma induced reactive oxygen species and damage of DNA molecule in HaCaT cells under euoxic and hypoxic condition. Journal of Radioanalytical and Nuclear Chemistry 302(2): 983-988.

Kameya H, Miyanoshita A, Imamura T, et al. (2012) Assessment of gamma ray-induced DNA damage in Lasioderma serricorne using the comet assay. Radiation Physics and Chemistry 81(3): 316-321.

Koo HN, Yoon SH, Shin YH, et al. (2011) Effect of electron beam irradiation on developmental stages of
Plutella xylostella (Lepidoptera: Plutellidae). Journal of Asia-Pacific Entomology 14(3): 243-247.

Koo HN, Yun SH, Yoon C, et al. (2012) Electron beam irradiation induces abnormal development and the stabilization of $\mathrm{p} 53$ protein of American serpentine leafminer, Liriomyza trifolii (Burgess). Radiation Physics and Chemistry 81(1): 86-92.

Lau AT, Wang Y and Chiu JF (2008) Reactive oxygen species: current knowledge and applications in cancer research and therapeutic. Journal of Cellular Biochemistry 104(2): 657-667.

Lee RF and Steinert S (2003) Use of the single cell gel electrophoresis/comet assay for detecting DNA damage in aquatic (marine and freshwater) animals. Mutation Research/Genetic Toxicology and Environmental Mutagenesis 544(1): 43-64.

Marczynski B, Rihs HP, Rossbach B, et al. (2002) Analysis of 8-oxo-7,8-dihydro-2'-deoxyguanosine and DNA strand breaks in white blood cells of occupationally exposed workers: comparison with ambient monitoring, urinary metabolites and enzyme polymorphisms. Carcinogenesis 23(2): 273-281.

Martinez-Paz P, Morales M, Martinez-Guitarte JL, et al. (2013) Genotoxic effects of environmental endocrine disruptors on the aquatic insect Chironomus riparius evaluated using the comet assay. Mutation Research/ Genetic Toxicology and Environmental Mutagenesis 758(1-2): 41-47.

Mitchelmore CL and Chipman JK (1998) DNA strand breakage in aquatic organisms and the potential value of the comet assay in environmental monitoring. Mutation Research/Genetic Toxicology and Environmental Mutagenesis 399(2): 135-147.

Mohankumar MN, Janani S, Prabhu BK, et al. (2002) DNA damage and integrity of UV-induced DNA repair in lymphocytes of smokers analysed by the comet assay. Mutation Research 520: 179-187.

Moller AP and Mousseau TA (2013) The effects of natural variation in background radioactivity on humans, animals and other organisms. Biological Reviews of the Cambridge Philosophical Society 88(1): 226-254.

Morales MN, MartÃnez-Paz P, OzÃ $j$ ez I, et al. (2013) DNA damage and transcriptional changes induced by tributyltin (TBT) after short in vivo exposures of Chironomus riparius (Diptera) larvae. Comparative Biochemistry and Physiology Part C: Toxicology \& Pharmacology 158(2): 57-63.

Rai KS, McDonald PT and Asman SM (1970) Cytogenetics of two radiation-induced,sex-linked translocations in the yellow-fever mosquito, Aedes aegypti. Genetics 66(4): 635-651. 
Rajaguru P, Vidya L, Baskarasethupathi B, et al. (2002) Genotoxicity evaluation of polluted ground water in human peripheral blood lymphocytes using the comet assay. Mutation Research 517: 29-37.

Rastogi RP, Singh SP, Incharoensakdi A, et al. (2014) Ultraviolet radiation-induced generation of reactive oxygen species, DNA damage and induction of UV-absorbing compounds in the cyanobacterium Rivularia sp. HKAR4. South African Journal of Botany 90: 163-169.

Revankar PR and Shyama SK (2009) Genotoxic effects of monocrotophos, an organophosphorous pesticide, on an estuarine bivalve, Meretrix ovum. Food and Chemical Toxicology 47(7): 1618-1623.

Saleha Banu B, Danadevi K, Rahman MF, et al. (2001) Genotoxic effect of monocrotophos to sentinel species using comet assay. Food and Chemical Toxicology 39(4): 361-366.

Seong KM, Kim CS, Seo SW, et al. (2011) Genome-wide analysis of low-dose irradiated male Drosophila melanogaster with extended longevity. Biogerontology 12(2): 93-107.

Shaposhnikov M, Proshkina E, Shilova L, et al. (2015) Lifespan and stress resistance in Drosophila with overexpressed DNA repair genes. Scientific Report 5: 15299.

Shaposhnikov MV, Turysheva EV and Moskalev AA (2009) Low-dose rate irradiation induced hormesis, hypersensitivity and adaptive response in Drosophila melanogaster of radiosensitive strains. Radiatsionnia Bioliia Radioecologiia 49(1): 46-54.

Sharma VP, Razdan RK and Ansari MA (1978) Anopheles stephensi: effect of gamma-radiation and chemosterilants on the fertility and fitness for sterile male releases. Journal of Economic Entomology 71: 449-450.

Shetty NJ (1983) Chromosomal translocations and semisterility in the malaria vector Anopheles fluviatilis James. Indian Journal of Malariology 20: 45-48.

Shetty NJ (1993) Genetic control of mosquitoes: chromosomal translocations and inherited semi-sterility in Culex quinquefasciatus - a filarial mosquito. Journal of Cytology and Genetics 28: 181-187.
Shetty V, Shetty NJ, Harini BP, et al. (2016) Effect of gamma radiation on life history traits of Aedes aegypti (L). Parasite Epidemiology and Control 1(2): 26-35.

Singh NP, McCoy MT, Tice RR, et al. (1988) A simple technique for quantitation of low levels of DNA damage in individual cells. Experimental Cell Research 175(1): 184-191.

Singhal RK, Ajay K, Usha N, et al. (2009) Evaluation of doses from ionising radiation to non-human species at Trombay, Mumbai, India. Radiation Protection Dosimetry 133(4): 214-222.

Tice RR, Agurell E, Anderson D, et al. (2000) Single cell gel/comet assay: guidelines for in vitro and in vivo genetic toxicology testing. Environmental and Molecular Mutagenesis 35(3): 206-221.

Todoriki S, Hasan M, Miyanoshita A, et al. (2006) Assessment of electron beam-induced DNA damage in larvae of chestnut weevil, Curculio sikkimensis (Heller) (Coleoptera: Curculionidae) using comet assay. Radiation Physics and Chemistry 75(2): 292-296.

UNSCEAR (2011) 2008 Report to the General Assembly with Scientific Annexes, Sources and effects of Ionizing radiation. New York: United Nations.

Vaiserman AM, Koshel NM, Litoshenko AY, et al. (2003) Effects of X-irradiation in early ontogenesis on the longevity and amount of the S1 nuclease-sensitive DNA sites in adult Drosophila melanogaster. Biogerontology 4(1): 9-14.

Wilson DM 3rd, Sofinowski TM and McNeill DR (2003) Repair mechanisms for oxidative DNA damage. Frontiers in Bioscience 8: d963-d981.

Wright A, Mercedes J, Delarosa M, et al. (2004) Freezing insects: the effects of cryopreservation protocols on nucleic acid degradation. In: CBC, Symposium, 24-26 March 2004. New York: American Museum of Natural History (AMNH).

Yun SH, Lee SW, Koo HN, et al. (2014) Assessment of electron beam-induced abnormal development and DNA damage in Spodoptera litura (F.) (Lepidoptera: Noctuidae). Radiation Physics and Chemistry 96: 44-49. 